\title{
The Impact of Memrise Application on Iranian EFL Learners' Collocation Learning and Retention
}

\author{
Zeynab Esmaeili \\ Department of English, Shahreza branch, Islamic Azad University,Shahreza, Iran \\ Email: esmaeilizeinab93@yahoo.com \\ Mohsen Shahrokhi \\ Department of English, Shahreza branch, Islamic Azad University,Shahreza, Iran \\ Email: mohsenshahrokhi@yahoo.com
}

Received: 23 September 2019

Reviewed: 16 May 2020

Accepted: 1 September 2020

\begin{abstract}
This study aimed at investigating the effect of Memrise application on Iranian EFL learners' collocation learning and retention. To this end, a quasi-experimental design was used. 75 Iranian intermediate EFL learners studying English at a private language institute, namely Farahan, Iran were selected to participate in the study based on convenience sampling in the form of two intact classes. The scores obtained were entered into SPSS software for the purpose of data analysis. The results of data analysis showed that Memrise application had a statistically differential effect on collocation learning of Iranian EFL learners. Moreover, it was demonstrated that Memrise application had a statistically differential effect on collocation retention of Iranian EFL learners. In addition, it was proved that there was a significant difference between the immediate post-test scores Iranian EFL learners who received Memrise application and those who received traditional teaching. Finally, it was indicated that there was a statistically significant difference between the delayed post-test scores of Iranian EFL learners who received Memrise application and those who received traditional teaching.
\end{abstract}

Keywords: Collocation Learning; Collocation Retention; Memrise application; Mobile Assisted Language Learning (MALL); Computer Assisted Language Learning (CALL).

\section{Introduction}

The use of technology in language learning and teaching began in early 1970s and since then, it has found its way into the field rapidly (Karakash \& Ersoy, 2011, as cited in Elyasi \& Pourkalhor, 2014). Some scholars (e.g., Agca \& Özdemir, 2012; Mayer, 2005) believe that technology makes foreign language materials easy to access and use and makes language learning more meaningful through personal engagement. "Technological developments in ubiquitous computing and wireless communication together with the adoption of mobile multimedia devices and applications have been converted into huge opportunities for English as a foreign language" (Rodríguez-Arancón, Arús \& Calle, 2013, p. 1189). Technology can be used in different forms in different fields. As a form of the use of technology in the field of English language learning/teaching, Mobile-assisted Language Learning (MALL) has been introduced as a teaching/learning methodology wherein mobile phones or other handheld 
devices with some form of wireless connectivity, such as phones, tablets are used (RodríguezArancón, Arús \& Calle, 2013).

Obviously, the last decades of the 20th century have been characterized with the development technology in human life. According to Namvar and Rastgoo (2008), the role of new technologies in changing education and improving learning and teaching in education cannot be ignored. Today, some universities and institutes use various technologies to apply virtual and distance education. Appearance of new technologies has an enormous effect on all levels of humans life and education also has been affected by these technologies. Internet and its facilities have the most effect in relate to other technologies. The belief is that technology can motivate students to write and do research and also read other person researches, give students a platform to explore and analyze the various internet materials they gain both independently out of the class and in the classroom (Orlova, 2003). Applications of technologies is considered as a shift of paradigms through which learners learn "How to learn" instead of "learning certain subjects and materials" and using them in education makes achieving this aim easily by providing students to write and publish their ideas, read other experts writings, create a cooperative and collaborative environments (Du \&Wagner, 2005).

A prominent manifestation of the use of technology in language learning is MALL. MALL has been emerged as an instance of technology use in which mobile phones are used to teach/learn English language (Rodriguez-Arancon, Arus \& Calle, 2013). As believed by Kuklska- Hulme and Shield (2008), MALL goes beyond the use of mobile phones and includes any portable learning materials. As rightly put by Muhammed (2013), mobiles have widely found their way in ELT and their significant effectiveness has been indicated in the field. As argued by Cobcroft, Towers, Smith, and Brunes (2006), mobile phones positively affect learning through creating enjoyable environments for learning. In the same vein, Stockwel (2007) considered the use of mobile phones as linked with language learning. Similarly, some scholars (e.g., Kukulska-Hulme \& Sheild, 2008; Stockwel, 2013) believed that the use of mobile phones in language learning enhances some psychological traits in learners, such as autonomy, motivation, self-efficacy, etc.

Empirically, some studies have been conducted on the MALL. Dashtestani (2013) probed into the attitudes of Iranian EFL teachers toward the implementation of MALL but did not investigate the attitudes of EFL students. He found that the participants have a positive attitude toward MALL. Miri and Rahimi (2014) examined the impact of mobile dictionary use on language learning in Urmia University and found a significant relationship between using mobile dictionary and language learning. Kamalaian and Sayadian (2014) studied the role of short messaging in Iranian EFL learners' vocabulary learning and motivation. The findings showed that mobile learning and short text massaging decreased the level of learners' stress, and improved the level of vocabulary learning and, enhanced learners' motivation. In a study by Wang, Teng and Chen (2015), two freshman English classes with a total of 74 students in a private university in Taiwan used Word Power App to learn British English. The vocabulary teaching process lasted twenty minutes each session. The results indicated that both learners and teachers were interested in using technology as a learning material. The learners who used iPad as the learning material showed a significantly better performance. Najmi (2015) examined the attitudes of Iranian upper-intermediate EFL learners toward MALL and its effect on their writing skill. The results of the study suggested that the majority of students had positive attitudes toward improving their writing skills through text messaging. Habbash (2015) investigated the effectiveness of using mobile devices in teaching vocabulary in EFL classes in Saudi Arabia as well as teachers' attitudes toward using mobile devices for teaching. The findings revealed that although the majority of teachers had positive attitudes toward mobile-assisted teaching, they did not use mobile devices in their classes since they believed students were not used to using mobile for educational purposes. An experimental study was 
conducted by Ghaemi and Golshan (2017) to examine the use of telegram on teaching vocabularies among Iranian intermediate EFL learners. To this aim, the mean differences between PET proficiency test, two time-series vocabulary progress tests, and a post-test were compared. The results indicated that the use of telegram had a significantly positive effect on learners' vocabulary learning.

As seen in the reviewed literature, MALL has been investigated from various viewpoints by the researchers. Besides, collocation learning and retention have been the main focus of several studies conducted before. However, obviously, the literature on MALL is not so rich. Furthermore, no study, to the best knowledge of the researcher, has dealt with the effect of Memrise application on Iranian EFL learners' collocation learning and retention. To fill this gap, this study was planned.

In fact, nowadays, mobiles are used widely in different countries and proved to be significantly effective on language learning (Muhammed, 2013). Kuklska- Hulme and Shield (2008) noted that MALL involves the use of any portable learning materials such as mobile phones, mp3/mp4 players, and palm computers. Likewise, Cobroft, Towers, Smith, and Bruns (2006) believe that mobile phones can create pleasant learning environments and have positive effects on learning. Therefore, it can be argued that the use of mobile phones in learning has some advantages for language learners (Kukulska-Hulme \& Sheild, 2008; Stockwel, 2013). One of the popular mobile applications is Memrise. As defined in memrise.com, Memrise is a user-generated learning platform which uses flashcards as memory aids. It specializes in language learning, but also offers content on a wide range of other subjects. Memrise has more than 150 language courses across 25 languages.

Moreover, among different aspects of English language learning, the role that collocations can play in the use of language has been shown over the years. Lesniewska (2006) believes that collocations are those combinations of words that are not absolutely fixed. Shin and Nation (2007) point out that the proper use of collocations helps learners to develop language fluency and native like language use. It appears that collocations play a very important role in the utilization of language (Ellis, 2001). Fan (2009) argues that although collocations are an essential part of language, they are somehow dubious for language learners; that is why collocations should be included as an important part in second language instruction. Moreover, the inevitable role which collocations play in the development of vocabulary knowledge is of little doubt (Koya, 2006) and it is believed that improvement in learners' knowledge of other aspects of language can be based on knowledge of collocations.

Since collocations play an important role in the coherence of the structure of language, learning and retention of them constitutes an important aspect of English learning. In supporting this saying, Shin and Nation (2007) argue that the proper use of collocations helps learners to develop language fluency and native like language use. Similarly, according to Ellis (2001), it appears that collocations play a very important role in the utilization of language and one thing that differentiates native and non-native speakers is being equipped with collocational proficiency. But it cannot be denied that collocations are among the challenging areas for English as Foreign Language (EFL) learners because different languages possess different world view on collocations (Wan Ramli, 2014). In other words, learning collocations is difficult for EFL learners and they have problems with this aspect of English learning. More specifically, many language learners suffer from their lack of collocational knowledge (Zarei $\&$ Khojasteh, 2018). In reducing the challenges and complexities of collocation learning and retention, the use of technology and MALL have been suggested as a solution (O'Malley, Vavoula, Glew, Taylor, Sharples, \& Lefrere (2003).

However, in spite of the proved potentials of MALL, it can be seen that in the Iranian educational system, using mobiles is not allowed in the educational settings including universities, schools, etc. In other words, having a glance at Iranian educational system shows 
that still traditional teaching methods and techniques are prevalent in many educational settings and just recently some forms of technological methods including Computer Assisted Language Learning (CALL) has come to be applied in some educational environments. But the use of cell-phones is not so popular in Iranian educational systems. Thus, generally, not much research has been conducted in this regard. Particularly, the researcher found that while MALL and collocation learning and retention have been touched by some researchers in different studies (e.g., Bahojb Jafarian \& Shoari, 2017; Ghaemi \& Golshan, 2017; Najmi, 2015; Taheri \& Davoudi, 2016; Wang, Teng \& Chen, 2015), so far, no Iranian study has touched the effect of Memrise application on Iranian EFL learners' collocation learning and retention. This is the gap this study aimed to fill. The purpose of the present study was to investigate whether Memrise application has any differential effect on collocation learning and retention of Iranian EFL learners. To fulfill the purpose of the present study, the following research questions were addressed:

1. Does Memrise application have any statistically differential effect on collocation learning of Iranian EFL learners?

2. Does Memrise application have any statistically differential effect on collocation retention of Iranian EFL learners?

3. Is there any statistically significant difference between collocation learning of Iranian EFL learners who receive Memrise application and those who receive traditional teaching?

4. Is there any statistically significant difference between collocation retention of Iranian EFL learners who receive Memrise application and those who receive traditional teaching?

\section{Method}

Design

The design of the present study was quasi-experimental in which two groups were exposed to two different types of treatment. Generally, in this type of design, experimental and control groups are used. The experimental group(s) is given the treatment but the control group does not receive it. However, the experimental and control groups undergo take the same tests in the form of pre-test and post-test. Memrise application served as the independent variable of the study, and collocationlearning and retention as the dependent variables.

Participants

The participants of this study included 75 Iranian intermediate EFL learners studying English at a private language institute, namely Farahan, Iran who were selected to participate in the study based on convenience sampling in the form of two intact classes. Then, they were homogenized through Oxford Placement Test (OPT). Having being homogenized, the sample was randomly divided into two groups, each consisting of 30 students (15 learners were excluded after homogenization) One group received Memrise application and the other one received traditional teaching. The participants' age ranged from 17 to 25 .

Instruments

The research used the following instruments for the purpose of data collection:

\section{Oxford Placement Test (OPT)}

The first instrument was a version of Oxford Placement Test (OPT) which was employed to ensure about the homogeneity of the participants at the outset of the study. This test was composed of 40 multiple choice items (20 items on grammar and 20 items on vocabulary). Reliability of the test was reported as .80 and its validity was confirmed through 
factor analysis (Wistner, Hideki, \& Mariko, 2013). For the purpose of this study, Cronbach's Alpha reliability of OPT was calculated 70.

Two collocation tests

Two already validated equivalent collocation tests, originally developed by Salimi, Tavakoli, and Ketabi (2011) in a Ph.D. thesis and taken from Zare Behtash and Etehadi (2016) for the purpose of this study, were used as the instruments in the present study. One of the tests was used as the pre-test and the other one as the immediate and delayed post-test. Each test consisted of 30 fill in the blank items in the form a sentence in which one word was omitted and there was a word or phrase in bold type. The missing word together with the bold type word or phrase constituted a collocation. A Persian equivalent of the collocation in question was also provided at the end of each sentence as a clue. Reliability and validity of the tests have been confirmed by Salimi, Tavakoli, and Ketabi (2011, as cited in Zare Behtash \& Etehadi, 2016). For the purpose of this study, Cronbach's Alpha reliabilities of the tests were .76 and .81 .

\section{Procedure}

Before starting the process of data collection, the formal procedures including taking the agreement of the authorities of the institute as well as the participants' consent, and ensuring confidentiality of the participants' information were conducted. To collect the data, first, the sample was selected through convenience sampling. Next, the sample was homogenized through OPT. Then, the homogenized sample was randomly divided into two groups, one group received Memrize application and the other one received traditional teaching. In the next stage, a pre-test (described in the section on instruments) was administered in the two groups. Then, the two groups benefited from eight educational sessions of the institute two times a week. Each session lasted about 90 minutes. Both groups enjoyed from the mainstream educational sessions of the institute. The only difference between the two groups was that one group was asked to install Memrise application on their mobile phone and use it in the last twenty minutes of the classroom under guidance of the teachers and at the home. However, in the other group, no use of any mobile application was made. To ensure that the first group used this application in home, each session the teacher asked them to give their feedback on the use of it. One week after the seven classes, the immediate post-test was administered in the two groups in 20 minutes. Moreover, three weeks later, the delayed post-test was administered in 20 minutes in the two groups. As mentioned above, the tests consisted of 30 fill in the blank items in the form a sentence in which one word was omitted and there was a word or phrase in bold type. The missing word together with the bold type word or phrase constituted a collocation. A Persian equivalent of the collocation in question was also provided at the end of each sentence as a clue.

\section{Data analysis}

To analyze the data, to check the normality assumption of the distribution of data, Kolmogorov-Smirnov test was run. Descriptive statistics was calculated to see the participants' performance pattern in the pre-test and immediate and delayed post-test. Besides, to investigate whether Memrise application has any statistically differential effect on collocation learning and retention of Iranian EFL learners, a Repeated Measures ANOVA was used. To see whether there is any statistically significant difference between collocation learning of Iranian EFL learners who received Memrise application and those who received traditional teaching, an independent samples t-test was run. Another independent samples t-test was run to see whether there is any statistically significant difference between collocation retention of Iranian EFL learners who received Memrise application and those who received traditional teaching. 


\section{Results}

In order to check the normality assumption of the distributed scores in Memrise and traditional groups, a one sample Kolmogorov-Smirnov Test was run (Table 1):

Table 1. Results of Kolmogorov-Smirnov Test

\begin{tabular}{llll}
\hline & $\mathrm{N}$ & $\begin{array}{l}\text { Test score Test score } \\
\text { (Memrise } \\
\text { group) }\end{array}$ & $\begin{array}{l}\text { (traditional } \\
\text { group) }\end{array}$ \\
\hline $\mathrm{N}$ & 60 & normal & normal \\
Normal Distribution & & & \\
Kolmogorov-Smirnov Z & & 0.71 & 0.75 \\
Asymp. Sig. (2-tailed) & & 0.25 & 0.39 \\
\hline
\end{tabular}

As indicated in Table 1, Memrise group $(\mathrm{z}=.71, \mathrm{p}=.25)$ and traditional group $(\mathrm{z}=.75$, $\mathrm{p}=.39$ ) were normally distributed.

Descriptive statistics was calculated to see the participants' performance in the pre-test and immediate and delayed post-tests. Tables 4.2, 4.3 and 4.4 show the results:

Table 2. Descriptive Statistics for the Pre-test

\begin{tabular}{|l|l|l|l|l|l|l|}
\hline & $\mathrm{N}$ & Mean & Std. Deviation & Std. Error & Minimum & Maximum \\
\hline Exp & 30 & 12.9667 & 3.74611 & 0.68394 & 7.00 & 18.00 \\
\hline Con & 30 & 12.2667 & 3.27933 & 0.59872 & 8.00 & 16.00 \\
\hline
\end{tabular}

Table 2 shows that the means of the experimental and control groups in the pre-test are 12.96 and 12.26. And the standard deviations of the two groups are 3.74 and 3.27.

Table 3. Descriptive Statistics for the Immediate Post-test

\begin{tabular}{|l|l|l|l|l|l|l|}
\hline & & & & & & \\
& $\mathrm{N}$ & Mean & Std. Deviation & Std. Error & Minimum & Maximum \\
\hline Exp & 30 & 16.5667 & 3.85677 & 0.70415 & 10.00 & 20.00 \\
\hline Con & 30 & 14.5000 & 2.14556 & 0.39172 & 8.00 & 16.00 \\
\hline
\end{tabular}

Table 3 indicates that the means of the experimental and control groups in the immediate post-test are 16.56 and 14.50. And the standard deviations of the two groups are 3.85 and 2.14 .

Table 4. Descriptive Statistics for the Delayed Post-test

\begin{tabular}{|lllllll|}
\hline & & & & & & \\
& $\mathrm{N}$ & Mean & Std. Deviation & Std. Error & Minimum & Maximum \\
\hline Exp & 30 & 24.1000 & 2.83269 & 0.51718 & 12.00 & 20.00 \\
\hline Con & 30 & 20.9000 & 2.76867 & 0.50549 & 9.00 & 15.00 \\
\hline
\end{tabular}

As seen in Table 4, the means of the experimental and control groups in the delayed post-test are 24.10 and 20.90. And the standard deviations of the two groups are 2.83 and 2.76.

To investigate whether Memrise application has any statistically differential effect on collocation learning and retention of Iranian EFL learners, a Repeated Measures ANOVA was used. Table 5 shows the results: 
Table 5. One-way Repeated Measures ANOVA of the Effect of Memrise Application on Learners' Collocation Learning and Retention

\begin{tabular}{|c|c|c|c|c|c|c|c|c|c|}
\hline \multicolumn{2}{|c|}{ Effect } & \multirow{2}{*}{$\begin{array}{l}\text { value } \\
\\
0.29 \\
3 \\
0.80 \\
5\end{array}$} & \multirow{2}{*}{$\begin{array}{l}\mathrm{F} \\
\\
4.81 \\
1 \\
4.81 \\
1\end{array}$} & \multirow{2}{*}{\begin{tabular}{|l|}
$\begin{array}{l}\text { Hypothesis } \\
\text { df }\end{array}$ \\
2.000 \\
2.000
\end{tabular}} & \multirow{2}{*}{$\begin{array}{l}\begin{array}{l}\text { Error } \\
\text { df }\end{array} \\
15.00 \\
0 \\
15.00 \\
0\end{array}$} & \multirow{2}{*}{$\begin{array}{l}\text { sig. } \\
0.04 \\
2 \\
0.04 \\
1\end{array}$} & $\begin{array}{l}\begin{array}{l}\text { Partial } \\
\text { Eta } \\
\text { Squared }\end{array} \\
0.195\end{array}$ & $\begin{array}{l}\begin{array}{l}\text { Noncent } \\
\text { parameter }\end{array} \\
14.26\end{array}$ & $\begin{array}{l}\text { Observe } \\
\text { d power }\end{array}$ \\
\hline Time & $\begin{array}{l}\text { Pillai's } \\
\text { trace } \\
\text { Wilk's } \\
\text { lambada }\end{array}$ & & & & & & $\begin{array}{l}0.195 \\
0.195\end{array}$ & $\begin{array}{l}14.26 \\
13.90\end{array}$ & $\begin{array}{l}.742 \\
.192\end{array}$ \\
\hline & $\begin{array}{l}\text { Hotellin } \\
\mathrm{g} \text { trace } \\
\text { Roy's } \\
\text { largest } \\
\text { root }\end{array}$ & $\begin{array}{l}0.24 \\
2 \\
0.24 \\
2\end{array}$ & $\begin{array}{l}4.81 \\
1 \\
4.81 \\
1\end{array}$ & $\begin{array}{l}2.000 \\
2.000\end{array}$ & $\begin{array}{l}15.00 \\
0 \\
15.00 \\
0\end{array}$ & $\begin{array}{l}0.04 \\
2 \\
0.04 \\
2\end{array}$ & $\begin{array}{l}0.195 \\
0.195\end{array}$ & $\begin{array}{l}17.62 \\
14.00\end{array}$ & $\begin{array}{l}.517 \\
.630\end{array}$ \\
\hline
\end{tabular}

According to the results of the repeated measures ANOVA, there was a significant effect for time. In other words, there was a significant the difference between the mean scores in pre-test, immediate post-test and delayed post-test $(\mathrm{F}=4.811, \mathrm{p}<0.05$, Wilk's lambada $=$ .805 , multivariate eta square $=.195)$. This means that Memrise application had a statistically differential effect on collocation learning and retention of Iranian EFL learners.

To see whether there is any statistically significant difference between collocation learning of Iranian EFL learners who received Memrise application and those who received traditional teaching, an independent samples t-test was run whose results can be seen in Table 6:

Table 6. Results of Independent Samples t-test for the Immediate Post-test

\begin{tabular}{|c|c|c|c|c|c|c|c|c|c|}
\hline & $\begin{array}{l}\text { Leve } \\
\text { for I } \\
\text { Varic } \\
\end{array}$ & $\begin{array}{l}\text { s Test } \\
\text { lality of } \\
\text { es }\end{array}$ & t-test & for & quality $\mathrm{c}$ & f Means & & & \\
\hline & & & & & $\begin{array}{l}\text { Sig. } \\
(2-\end{array}$ & Mean & Std. Error & $\begin{array}{l}95 \% \\
\text { Confid } \\
\text { Interva } \\
\text { Differe }\end{array}$ & $\begin{array}{l}\text { nce } \\
\text { of the } \\
\text { cee }\end{array}$ \\
\hline & $\mathrm{F}$ & Sig. & $\mathrm{t}$ & $d f$ & tailed) & Difference & Difference & \begin{tabular}{|l|} 
Lower \\
\end{tabular} & Upper \\
\hline \begin{tabular}{|l} 
Equal \\
variances \\
assumed
\end{tabular} & 3.13 & 0.08 & $\begin{array}{l}- \\
0.61\end{array}$ & 1 & 0.04 & -0.24 & 0.39 & -1.02 & 0.54 \\
\hline
\end{tabular}

As seen in Table 4.6, there is a significant $(\mathrm{t}=-.61, \mathrm{p}<.05)$ difference between the posttest scores of Iranian EFL learners who received Memrise application and those who received traditional teaching in the immediate post-test.

Another independent samples t-test was run to see whether there is any statistically significant difference between collocation retention of Iranian EFL learners who received Memrise application and those who received traditional teaching. The results are shown in Table 7: 
Table 7. Results of Independent Samples t-test for the Delayed Post-test

\begin{tabular}{|c|c|c|c|c|c|c|c|c|c|}
\hline & \multicolumn{2}{|c|}{$\begin{array}{l}\text { Levene's Test } \\
\text { for Equality of } \\
\text { Variances }\end{array}$} & \multicolumn{7}{|c|}{ t-test for Equality of Means } \\
\hline & \multirow[b]{2}{*}{$\mathrm{F}$} & \multirow[b]{2}{*}{ Sig. } & \multirow[b]{2}{*}{$\mathrm{t}$} & \multirow[b]{2}{*}{ df } & \multirow{2}{*}{$\begin{array}{l}\text { Sig. } \\
(2- \\
\text { tailed) }\end{array}$} & \multirow{2}{*}{$\begin{array}{l}\text { Mean } \\
\text { Difference }\end{array}$} & \multirow{2}{*}{$\begin{array}{l}\text { Std. Error } \\
\text { Difference }\end{array}$} & \multicolumn{2}{|c|}{$\begin{array}{l}95 \% \\
\text { Confidence } \\
\text { Interval of the } \\
\text { Difference }\end{array}$} \\
\hline & & & & & & & & Lower & Upper \\
\hline $\begin{array}{l}\text { Equal } \\
\text { variances } \\
\text { assumed }\end{array}$ & 0.14 & 0.70 & 5.87 & 1 & 0.00 & 2.64 & 0.44 & 1.73 & 3.54 \\
\hline
\end{tabular}

According to Table 7 , there was a statistically significant $(\mathrm{t}=5.87, \mathrm{p}<.05)$ difference between collocation retention of Iranian EFL learners who received Memrise application and those who received traditional teaching.

\section{Discussion and conclusion}

Four research questions were addressed in the present study. In this section, the questions were answered based on the obtained results. Moreover, the results are justified and compared with the findings of the previous studies.

To answer the first research question which dealt with the effect of Memrise application on collocation learning of Iranian EFL learners, a Repeated Measures ANOVA was run the results of which showed that Memrise application had a statistically differential effect on collocation learning of Iranian EFL learners.

Answering the second research question which addressed the effect of Memrise application on collocation retention of Iranian EFL learners also requires referring to the results of the Repeated Measures ANOVA which demonstrated that Memrise application had a statistically differential effect on collocation learning and retention of Iranian EFL learners.

To find an answer to the third research question on the difference between collocation learning of Iranian EFL learners who received Memrise application and those who received traditional teaching, an independent samples $t$-test was used and it was proved that there was a significant difference between the immediate post-test scores Iranian EFL learners who received Memrise application and those who received traditional teaching.

In an attempt to answer the fourth research question on the difference between collocation retention of Iranian EFL learners who received Memrise application and those who received traditional teaching, another independent samples $t$-test was run which indicated that there was a statistically significant difference between the delayed post-test scores of Iranian EFL learners who received Memrise application and those who received traditional teaching.

The findings of the present study are consistent with Kamalaian and Sayadian's (2014) study which studied the role of mobile learning in Iranian EFL learners' vocabulary learning and showed that mobile learning had a significant effect on the level of vocabulary learning among the participants. Another study whose results are in line with those of the present study is an experimental study by Ghaemi and Golshan (2017) which examined the impact of the use of mobile applications on vocabulary learning among Iranian intermediate EFL learners. The results indicated that the use of mobile had a significantly positive effect on learners' vocabulary learning. Moreover, in the research conducted by Habbash (2015), the effectiveness of using mobile devices in teaching vocabulary in EFL classes was revealed. The findings of the current study also implicitly supports the findings of Basal, Yilmaz, Tanriverdi and Sari's 
(2016) study in which the effectiveness of mobile applications on learning English idioms was investigated and it was suggested that the group which used mobile application as their teaching material performed significantly better than the control group. There are some other studies in the literature which showed the effectiveness of mobile applications on different skills of English learning, among which those by Miri and Rahimi (2014), and Wang, Teng and Chen (2015) can be mentioned.

As a justification for the finding of the present study, it can be said that learners has a positive attitude toward mobile applications and this leads to improvements in their language performance (Najmi, 2015). Another justification is that mobile applications increase learners' motivation to learn language and this leads to higher levels of performance among them (Kamalaian \& Sayadian, 2014). Furthermore, the researcher believes that another possible justification for the positive effect of Memrise application on collocation learning and retention is that mobile applications increase learners' autonomy and this in turn leads to their significant improvement in language learning.

All in all, the results of the present study showed the significant effect of Memrise application on collocation learning and retention among Iranian EFL learners. Accordingly, EFL teachers are recommended to use this application in an attempt to make English learning easier for EFL learners. Given that collocation learning and retention are indispensable parts of English learning, the finding of the present study is promising for English Language Teaching (ELT) stakeholders especially EFL learners.

In conclusion, the results showed that Memrise application had a statistically differential effect on collocation learning of Iranian EFL learners. Moreover, it was demonstrated that Memrise application had a statistically differential effect on collocation learning and retention of Iranian EFL learners. In addition, it was proved that there was a significant difference between the immediate post-test scores of Iranian EFL learners who received Memrise application and those who received traditional teaching. Finally, it was indicated that there was a statistically significant difference between the delayed post-test scores of Iranian EFL learners who received Memrise application and those who received traditional teaching. It cannot be denied that collocation learning and retention have been acknowledged as inseparable parts of language learning. Meanwhile, they are too difficult to be learned easily by EFL learners (Laufer, 1998, 89). As acknowledged by the scholars (i.e., Cameron, 2001; Holden, 2001), the retention and retrieval of collocations are considered as two difficult and challenging areas for EFL learners in learning English, despite their important role in language learning. As revealed by the results, Memrise application is significantly effective in EFL learners' collocation learning and retention. Thus, this application can be appropriately used as a supplementary tool in helping EFL learners to learn and retain English collocations. In this way, EFL learners may learn and retain English collocations with less difficulty. Taking the recent arguments for the effectiveness of MALL, it is hoped that using Memrise application contributes to remarkable improvements in collocation learning and retention and consequently the English proficiency of EFL learners. However, it can be seen that although MALL has been suggested as a solution to make English learning easier for EFL learners, using mobiles is not allowed in the educational settings of Iran including universities, schools, etc. In other words, having a glance at Iranian educational system shows that still traditional teaching methods and techniques are prevalent in many educational settings and just recently, some forms of technological methods including CALL has come to be applied in some educational environments. But the use of cell-phones is not so popular in Iranian educational systems.

Based on the results of this study, it can be concluded the above situation is not appropriate and there is a need for some changes in the educational system of Iran so that English teachers and learners can benefit from mobile applications in English classes. 
Interestingly, in the literature, it has been shown that both teachers and learners had a positive attitude towards mobile applications and preferred to use them in the English classes. Therefore, it seems that the time has reached for the arrival of mobile applications in the English classes in Iran, as supplementary to traditional methods of ELT.

Pedagogical implications

The first implication of the study was that EFL teachers can use Memrise application as a supplementary tool in their classes in trying to improve their students' collocation learning and retention. The second implication was that EFL learners should ask their teachers to use mobile applications in English classes. As the third implication, the parents can encourage the use of Memrise application by their children at home with the aim of improving their collocation learning and retention. Finally, material designers should develop the educational materials in a way that the use of mobile applications including Memrise application is encouraged in English classes.

Declaration of conflicting interest

The authors declare that there is no conflict of interest concerning the publication of this paper.

Funding acknowledgement

The authors received no specific funding for this work.

\section{References}

Agca, R.K., \& Özdemir, S. (2012). Foreign language vocabulary learning with mobile technologies. Procedia - Social and Behavioral Sciences, 83, $781-785$.

Bahojb Jafarian, R., \& Shoari, E. (2017). The effect of games on Iranian young EFL learners' vocabulary learning. European Journal of English Language and Literature Studies, 5 (2), 12-24.

Basal, A., Yilmaz, S., Tanriverdi, A., \& Sari, L. (2016). Effectiveness of mobile applications in vocabulary teaching. Contemporary Educational Technology, 7(1), 47-59.

Cameron, K. (1999). CALL and the learning community. Elm Bank Publications.

Cobobcroft, R.S., Towers, S.J., Smith, J.E., \& Brunes, A. (2006). Mobile learning in review: Opportunities and challenges for learners, teachers and institutions. Paper presented at Online Learning and Teaching Conference (OLT), Queensland University of Technology, Brisbane.

Dashtestani, R. (2013). Implementing mobile assisted language learning an EFL context: Iranian EFL teachers on challenges and affordance. JALTCAL Journal, 9(2), 149-146.

Du, H.S., \& Wagner, C. (2005). Learning with weblogs: An empirical investigation. Proceedings of the 38th Annual Hawaii International Conference on System Sciences (HICSS-38). Los Alamitos: IEEE Computer Society.

Ellis, N. C. (2001). Memory for language. In P. Robinson (Ed.), Cognition and second

language instruction (pp. 33-68). Cambridge: Cambridge University Press.

Elyasi, L., \& Pourkalhor, O. (2014). The effect of recorded instructional TV programs and traditional teaching on Iranian high school students. Asian Journal of Management Sciences \& Education, 3 (3), 125-131.

Fan, M. (2009). An exploratory study of collocational use by ESL students: A task based approach. System, 37(1), 110-123.

Ghaemi, F., \& Golshan, N. S. (2017). The Impact of telegram as a social network on teaching English vocabulary among Iranian intermediate EFL learners. International Journal of Information and Communication Sciences, 2(5), 86-98. 
Habbash, M. (2015). Learning English vocabulary using mobile phone: Saudi Arabian EFL teachers focus. European Scientific Journal, 11(35), 446-458.

Holden, W. (2001). Developing teachers in teaching vocabulary to L2 learners. Retrieved from http:// exchanges. State. Gov / forum / vols 34/ no 4 / p 77 Htm Kendall.pdf

Kamalian, A., \& Sayadian, S. (2014) .The role of text messaging in an Iranian EFL vocabulary learning and motivation. Science Journal of Education, 2(4), 101-107.

Koya, T. (2006). What is the reality of collocation use by native speakers of English? Dialogue, $5,1-18$.

Kukulska-Hulme, A., \& Sheild, L. (2008). An overview of mobile assisted language learning: from content delivery to support collaboration and interaction. Cambridge: Cambridge University Press.

Laufer, B. (1998). The development of passive and active vocabulary in a second language same or different. Applied linguistics 19, 255-271.

Lesniewska, J. (2006). Collocations and second language use. Studia Linguistica, 123, 95-105.

Mayer, R.E. (2005). Introduction to multimedia learning, in R.E. Mayer (ed.) The Cambridge handbook of multimedia learning. Cambridge: Cambridge University Press.

Miri, S.Sh., \& Rahimi, M. (2014).The impact of mobile dictionary use on language learning. ELSEVIER Journal, 18(98), 1469-1474.

Muhammed, A.A. (2013). The impact of mobiles on language learning on the part of English Foreign Language (EFL) university students. Procedia - Social and Behavioral Sciences, 136, $104-108$.

Najmi, K. (2015).The effect of mobile-assisted language learning on guided writing skill of Iranian upper inter-mediate learners. Journal of Applied Linguistic and Language Research, 2(4), 42-52.

Namvar, Y., \& Rastgoo, A. (2008). Weblog as a learning tool in higher education. Turkish Online Journal of Distance Education, 9 (3), 176-185.

O’Malley, C., Vavoula, G., Glew, J. P., Taylor, J., Sharples, M., \& Lefrere, P. (2003). MOBIlearn WP4 - Guidelines for learning/teaching/tutoring in a mobile environment. http://www.mobilearn.org/download/results/guidelines.pdf

Orlova, N. F. (2003). Helping prospective EFL teachers learn how to use songs in teaching conversation classes. The Internet TESL Journal, 9, 1-13.

Rodríguez-Arancón, P., Arús,J., \& Calle, C. (2013). The use of current mobile learning applications in EFL. Procedia - Social and Behavioral Sciences, 103, 1189 - 1196.

Shin, D. \& Nation, P. (2007). Beyond single words: the most frequent collocations in spoken English. ELT Journal, 62(4), 339-348.

Stockwell, G. (2013). Tracking learner usage of mobile phones for language learning outside of the classroom. In P. Hubbard, M. Schulz .B. Smith (Eds), Learner-computer interaction in language education: A festschrift in honor of Robert Fischer (pp. 118136). San Marcos, TX: CALICO.

Taheri, M., \& Davoudi, A.A. (2016). The effect of the keyword method on vocabulary learning and long-term retention. International Journal of Language and Linguistics, 3 (1), 114125.

Wang, B. T., Teng, C. W., \& Chen, H. T. (2015). Using iPad to facilitate English vocabulary learning. International Journal of Information and Education Technology, 5(2), 100116.

Wan Ramli, W.N.H. (2014). The translation of simile in the Hunger Games Novel: Translation strategies. E-proceedings of the Conference on Management and Muamalah. 
Wistner, B., Hideki, S., \& Mariko, A. (2013). An analysis of the Oxford Placement Test and the Michigan English Placement Test as L2 proficiency tests. Retrieved from https://www.hosei.ac.jp/bungaku/museum/html/kiyo/58/articles/Wistner.pdf

Zare Behtash, E., \& Etehadi, M. (2016). The impact of decision-making tasks and production tasks on the collocational knowledge of Iranian intermediate EFL learners. Iranian Journal of English for Academic Purposes, 5(2), 1-25.

Zarei, A.A., \& Khojasteh, A. (2018). The effect of dynamic assessment on EFL learners' collocational knowledge. M.A thesis. International University of Imam Khomeini. Foreign Languages Department. 